ACTA VET. BRNO, 55, 1986: 2S3-303

\title{
SURVEY OF REPRODUCTIVE INDICES OF CROSSES OF THE BOHEMIAN PIED WITH AYRSHIRE CATTLE AND THE RED HOLSTEIN BREED
}

\section{P. BRAUNER}

Department of Prevention of Pig Diseases, Animal Breeding and Zoohygiene, University of Veterinary Science, 61242 Brno

Received October 3, 1985

\section{A b s t r a c t}

B r a u n e r P.: Survey of Reproductive Indices of Crosses of the Bohemian Pied with Ayrshire Cattle and the Red Holstein Breed. Acta vet. Brno, 55, 1986: 293-303.

The average age at conception was the lowest in heifers of the Bohemian Pied X Red Holstein crosses (CR), followed by heifers of the Bohemian Pied cattle (C) and crosses of the Bohemian Pied $X$ Ayrshire breed, i.e. $509.35,521.09$ and 522.72 days, respectively. The average age at the lst calving was again the lowest in the CR crosses, followed by $C A$ and.C (789.76, 804.90 and 806.72 days, respectively). The CR crosses had the shortest pregnancy for the lst till 3rd lactations (1st - 280.41, 2nd - 283.60 and 3 rd - 286.60 days). The A.I. index (i.e. number of inseminations necessary for conception) for the lst lactation was $1.66,1.96$ and 1.84 in the CR, CA and C groups, respectively; for the 2 nd lactation it was $1.83,1.61$ and 2.17 in the $C R, C$ and $C A$ groups, respectively; for the 3 rd lactation $1.87,1.75$ and 1.48 in CR, $C$ and $C A$, respectively. The percentage of conceptions after the lst insemination was $62.86 \%, 48.84 \%$ and $47.36 \%$ in CR, C and CA, respectively, for the lst lactation; $50.88 \%$ in CR, $51.61 \%$ in $C$ and $47.92 \%$ in CA for the 2nd lactation, and 54,84\% in CR, $62.50 \%$ in $C$ and $60.00 \%$ in CA for the $3 r d$ lactation. The interval in CR, C and CA was $58.73,59.53$ and 59.55 days, respectively, for the lst lactation; for the 2nd lactation it was 54.75 , 55,19 and 53.46 days in the CR, C and CA, respectively; for the 3 rd lactation $62.09,69.50$ and 60.32 days in $C R, C$ and $C A$, respectively. The length of the service period (SP) was 82.30 , 93.30 and 93.78 days in CR, C and CA, respectively, for the lst lactation; $83.88,78.03$ and 97.00 days in CR, $C$ and $C A$ for the 2nd lactation; and $92.65,93.88$ and 75.99 days in $C R, C$ and $C A$ for the $3 r d$ lactation. The calving interval for the ist lactation in CR, C and CA was $366.74,381.23$ and 382.76 days, respectively; for the 2nd lactation it was $369.26,363,89$ and 380.89 days in CR, C and CA; for the 3rd lactation $374.79,387.42$ and 365.17 days. Evaluations of reproductive indices of the individual breeding groups according to the sequence of lactations showed that they were the most favourable in group CR. for the lst lactation, whereas for the 2 nd lactation it was group $C$ and for the $3 r d$ 
lactation it was group CA. Within the individual groups in all the three lactations no significant differences in the reproductive indices were found. The overall fertility was found to be favourable.

Cattle crossing, Bohemian Pied, Ayrshire, Red Holstein, reproductive indices.

The source of reserves is, along with maintaining a good health condition of the animals, intentional crossing and selection of animals in which the characters required are above the average of the population. Crossings with foreign dairy breeds are done so that the genes with the characters required would immigrate into the genetic pool of Czechoslovak breeds in order to breed high-yielding cattle adapted to conditions of large-scale production.

The aim of the present study was to evaluate the reproductive indices of crosses of the Bohemian Pied $X$ Red Holstein cattle and Ayrshire breeds as compared with the Bohemian cattle under field conditions of the University of Veterinary Science Training Farm in Nový Jičín.

The Holstein-Friesian breed ranks among the world's best milk-yielding cattle what has been the object of interest in many European countries. Many authors studied the reproductive indices. $\mathrm{SuCh}$ a nek and $\mathrm{Nejezchleba}$ (1976) reported that the average age at the lst calving was $25-27$ months ( $761-820$ days). Also the age of daughters of Red Holstein bulls at calving was favourable - 27 months on average, i. e. by 25 days shorter than that of their Bohemian Pied herd mates. At the lst calving the average age of CR 25 crosses ( $S$ u chánek et al. 1979) was 799 days, i. e. by 66 days earlier than that of their Bohemian Pied herd mates. Suchánek et al. (1979, 1981) further reported that the age of the Bohemian Pied X Holstein crosses (CR 25) was lower by about one month to 50 days than that of the Bohemian Pied cattle. Due to a quicker weight increment, P o l ás ek and $\mathrm{Such}$ a nek (1973) found that the age of the CA crosses at the lst calving was by 26.8 days lower than that of the Bohemian Pied Within the breeds the age of the CA crosses at calving was by 5 - 13 days lower ( $S$ u $c h$ a ne $k$ 1980). The age of the $C A$ crosses at the lst calving was slightly lower, i. e. by $10-20$ days as compared with their $C$ herd mates ( $S$ u chánek et al. 1980).

Vá cha l et al. (1976) compared the length of pregnancy between mothers of the Bohemian Pied breed which was 286.3 days, and mothers of $C R$ crosses which was shorter by 2.8 days $(P<0.01)$. $\mathrm{Such}$ án e $\mathrm{k}$ and $\mathrm{Nejezchleba}$ (1977) observed that pregnancy was by 0.5 - 1 day shorter in primiparas. With crosses the gravidity was shorter by 4.3 days in the $F_{1}$ generation of $C R 50$ and by 2.8 days in CR 25 as compared with the C herd mates where gravidity lasted for 289.1 days (S uchá nek et al. 1977).

$P$ o l ás e $k$ and $S u c h$ ánek (1973) reported that the SP for the lst lactation in Bohemian Pied cows and CA crosses was nearly the same, i.e. 95.1 and 98.4 days, respectively, the average calving interval being 387.4 and/or 385.7 days. They observed that the SP in CA crosses for the 2 nd lactation was markedly shorter ( 98.8 days) than in the Bohemian Pied breed (108.9 days). 
Suchánek (1974) found that the average calving interval in. the CA crosses was 385 - 398 days. U I r y ch and S u chan e (1977) reported that the average SP in CA crosses of the $F_{110}$ generation in the lst lactation was shorter as compared with crosses with a $50 \%$ proportion of Ayrshire blood: U l rych (1978) then investigated CA crosses from bulls imported from Canada with a good conception rate after the lst insemination $(57.4-58.5 \%)$ and a favourable index of fertility (i.e. number of born calves per 100 cows) of 101.8 - $103.9 \%$. The advantage of the Bohemian Pied cattle in large-scale cow-houses, according to $S$ uch a nek et al. (1980), is a very good fertility expressed in the length of the SP ( 90.2 and/or 90.1 days) what is, however, connected with their low efficiency. Suchánek et al. (1984) suggested that the CA crosses have a stronger constitution than the $C$ group in large-scale cow-houses which is manifested in better fertility indices (conception after the lst insemination is by + $1.6 \%$ higher, the length of the SP is by 4.4 days shorter). Suchá nek et al. (1978) compared the CR 25 crosses with herd mates of the $C$ breed and they found that the conception rate was better, the A.I. index being 1.23 , i. e. by 0.34 lower than in the Bohemian Pied cows. According to $C h r e n e k$ and Plesnik (1975), crossing the Slovakian Pied cattle with bulls of the Red Pied Lowland breed did not affect fertility as compared with the Slovakian Pied breed. In the Slovakian Pied $X$ Holstein-Friesian cattle Kon č a et al. (1979) proved significant differences in the interval between the lst and 2 nd calving.

\section{Materials and methods}

The study was carried out as a comparative experiment with three groups of cows: Bohemian Pied, Bohemian Pied X Red Holstein crosses with a $50 \%$ blood proportion and Bohemian Pied $X$ Ayrshire crosses with a blood proportion ranging between $25 \%$ - $53.25 \%$. The groups of animals selected for the investigations were constant, their number decreasing due to culling and continuing lactations. In order to maintain identic environmental conditions these groups were concentrated at the Ženklava farm. Late pregnant heifers and those in the lst lactation were housed in the primigravida shed an those in the 2 nd and 3 rd lactations were transferred into a large-capacity cowbarn with stanchions and slatted draining well.

The differences among the groups were studied in the age at conception, at lst calving and in the length of pregnancy before the lst, 2nd and 3 rd calving. The following reproductive indices were studied: insemination (A.I.) index, interval, calving. interval and $\%$ or conceptions after the lst insemination. In all the groups compared, the reproductive indices were studied according to the individual lactations. The data obtained were analyzed using common methods of variation statistics. 
The average age of the groups of heifers compared at conception (Tab. 1) was the lowest in the CR crosses ( 509.35 days), followed by group $C$ ( 11.74 days more) and the CA crosses ( 13.37 days more). The average age at the lst calving (Tab. 2) was again the lowest in the CR group ( 789.76 days); in group CA and $C$ it was by 15.14 and 16.96 days more, respectively.

Table 1

Average age at conception of the compared groups of heifers expressed in days

\begin{tabular}{|c|c|c|c|c|c|c|c|c|c|c|}
\hline \multirow[b]{2}{*}{ Group } & \multirow{2}{*}{$\begin{array}{l}\text { Number } \\
\text { of } \\
\text { animals }\end{array}$} & \multirow[b]{2}{*}{$\bar{x}$} & \multirow[b]{2}{*}{ SD } & \multirow[b]{2}{*}{ SEM } & \multirow[b]{2}{*}{$v \%$} & \multicolumn{2}{|c|}{$F$ - test } & \multirow{2}{*}{$\begin{array}{l}\text { Groups } \\
\text { compar- } \\
e^{\text {ed }}\end{array}$} & \multicolumn{2}{|c|}{$t$ - test } \\
\hline & & & & & & value & $\begin{array}{l}\text { signi- } \\
\text { ficance }\end{array}$ & & value & $\begin{array}{l}\text { signi- } \\
\text { ficance }\end{array}$ \\
\hline $\begin{array}{l}\text { CR } \\
C \\
C A\end{array}$ & $\begin{array}{l}83 \\
64 \\
82\end{array}$ & $\begin{array}{l}509.4 \\
521.1 \\
522.7\end{array}$ & $\begin{array}{l}73.29 \\
83.74 \\
65.05\end{array}$ & $\begin{array}{r}8.05 \\
10.43 \\
7.18\end{array}$ & $\begin{array}{l}14.32 \\
16.02 \\
12.44\end{array}$ & 0.51 & - & $\begin{array}{l}C R: C \\
C R: \text { CA } \\
C: \text { CA }\end{array}$ & $\begin{array}{l}0.72 \\
1.01 \\
0.13\end{array}$ & $\begin{array}{l}- \\
- \\
-\end{array}$ \\
\hline
\end{tabular}

Table 2

Average age at lst calving expressed in days

\begin{tabular}{llllrrrrrrr}
\hline CR & 83 & 789.8 & 75.46 & 8.28 & 9.56 & & CR : & C & 1.27 & - \\
C & 64 & 806.7 & 85.08 & 10.63 & 10.55 & 1.22 & - & CR : CA & 1.39 & - \\
CA & 82 & 804.9 & 62.51 & 6.90 & 7.77 & & & C : CA & 0.15 & - \\
\hline
\end{tabular}

The length of pregnancy (Tab. 3) in the heifers before the lst calving was 280.41 days in the CR crosses; in the CA crosses and group ' $C$ it was 1.77 and 5.22 days longer, respectively. The $C R$ crosses had the shortest 2 nd pregnancy ( 283.60 days); in the CA group and $C$ group it was by 1.82 and 5.56 days longer, respectively. By the $3 r d$ calving, the length of pregnancy was nearly the same in the individual groups. In the individual groups the length of pregnancy (Tab. 4) was as follows: in the CR crosses it was $280.41,283.60$ and 286.60 days for the lst, 2 nd and $3 r d$ pregnancy, respectively; in group C it was 285.63 for the lst pregnancy, 289.16 for the 2 nd and merely 286.74 days for the $3 r d ;$ in the CA crosses the length of the lst, 2nd and 3 rd pregnancy was $282.18,285.42$ and 287.40 days, respectively.

Tab. 5 gives a survey of reproductive indices of the individual breeding groups according to the sequence of lactations. It is evident that the CR group has the most favourable reproductive indices for the lst lactation. For the 2nd lactation 
Table 3

Length of pregnancy in experimental breeding cows expressed in days

Number
$\begin{gathered}\text { Group of } \\ \text { animals }\end{gathered} \quad$ SD $\quad$ SEM $v \% \frac{F-\text { test Groups }}{\text { value signi- compar- }} \begin{aligned} & t-\text { test } \\ & \text { ficance }\end{aligned}$

\begin{tabular}{|c|c|c|c|c|c|c|c|c|c|}
\hline $\begin{array}{l}\text { CR } \\
C \\
\text { CA }\end{array}$ & $\begin{array}{l}83 \\
64 \\
82\end{array}$ & $\begin{array}{l}280.4 \\
285.6 \\
282.2\end{array}$ & $\begin{array}{l}5.82 \\
7.93 \\
9.11\end{array}$ & $\begin{array}{l}0.64 \\
0.99 \\
1.01\end{array}$ & $\begin{array}{ll}2.08 & \\
2.78 & 13.05 \\
3.23 & \end{array}$ & ++ & $\begin{array}{l}\text { CR : } \\
\text { CR : } \\
\text { C : }\end{array}$ & $\begin{array}{l}\text { : } \\
\text { CA } \\
\text { CA }\end{array}$ & $\begin{array}{l}4.57 \\
1.48 \\
2.38\end{array}$ \\
\hline
\end{tabular}

up to 2nd calving

$\begin{array}{lllllllllllll}\text { CR } & 70 & 283.6 & 9.14 & 1.12 & 3.32 & & & \text { CR : } & \text { C } & 3.02 & ++ \\ \text { C } & 43 & 289.2 & 9.42 & 1.44 & 3.26 & 4.63 & ++ & \text { CR : CA } & 1.08 & - \\ \text { CA } & 57 & 285.4 & 9.37 & 1.24 & 3.28 & & & \text { C : } & \text { : CA } & 1.95 & -\end{array}$

up to 3rd calving

$\begin{array}{lllllllllll}\text { CR } & 57 & 286.6 & 7.83 & 1.04 & 2.73 & & & \text { CR : C } & 0.08 & - \\ \text { C } & 31 & 286.7 & 7.16 & 1.29 & 2.50 & 0.15 & - & \text { CR : CA } & 0.52 & - \\ \text { CA } & 48 & 287.4 & 7.60 & 1.10 & 2.64 & & & \text { C : CA } & 0.38 & -\end{array}$

$+P<0.05 \quad++P<0.01$

these indices are the best in group $C$ and in the $3 r d$ lactation for the $C A$ crosses. Due to culling the number of animals decreased in the further lactations.

Tab. 6 gives the statistical analysis of reproductive indices according to the sequence of lactations within the breeding groups compared.

\section{Discussion}

Suchánek and Nejezchleba (1976), Suchánek (1978), S u chánek et al. (1979, 1981) and Vách a l (1983) reported that the average age of the CR crosses at the lst calving was shorter by 0.2 - 2.0 months than that of the herd mates of group $C$. The age of the CA crosses was slightly lower at the lst calving; accordint to S u chán e k and Ulrych (1976), P o lás š k and Suchánek (1973), Suchánek (1980) and Suchánek et al. (1980) the age at the lst calving decreases by 5 - 20 days as compared with the herd mates of group $C$. The differences found in the present study were shorter by 16.96 days as compared with group $C$ and the average age of the CA crosses at the lst calving was found to be only 1.8 days less than that of the herd mates of group C. 
Table 4

Length of pregnancy within the individual experimental groups expressed in days

\begin{tabular}{|c|c|c|c|c|c|c|c|c|c|c|}
\hline \multirow{2}{*}{\multicolumn{2}{|c|}{$\begin{array}{l}\text { Number Sequen- } \\
\text { of ani- ce of } \\
\text { mals gravi- } \\
\text { dity }\end{array}$}} & \multirow{2}{*}{-} & \multirow[b]{2}{*}{ SD } & \multirow[b]{2}{*}{ SEM } & \multirow[b]{2}{*}{ v \% } & \multicolumn{2}{|c|}{$F$ - test } & \multirow{2}{*}{$\begin{array}{l}\text { Length } \\
\text {-of gra- } \\
\text { vidity } \\
\text { ecompared }\end{array}$} & \multicolumn{2}{|c|}{$t$ - test } \\
\hline & & & & & & value & $\begin{array}{l}\text { signi- } \\
\text { ficance }\end{array}$ & & value & $\begin{array}{l}\text { signi- } \\
\text { ficance }\end{array}$ \\
\hline \multicolumn{11}{|c|}{ Group CR } \\
\hline $\begin{array}{l}83 \\
70 \\
57\end{array}$ & $\begin{array}{l}1 \\
2 \\
3\end{array}$ & $\begin{array}{l}280.4 \\
283.6 \\
286.6\end{array}$ & $\begin{array}{l}5.28 \\
9.40 \\
7.83\end{array}$ & $\begin{array}{l}0.64 \\
1.12 \\
1.04\end{array}$ & $\begin{array}{l}2.08 \\
3.31 \\
2.73\end{array}$ & 10.89 & ++ & $\begin{array}{l}1: 2 \\
1: 3 \\
2: 3\end{array}$ & $\begin{array}{l}2.55 \\
5.32 \\
1.91\end{array}$ & $\begin{array}{l}++ \\
++ \\
-\end{array}$ \\
\hline \multicolumn{11}{|c|}{ Group C } \\
\hline $\begin{array}{l}64 \\
43 \\
31\end{array}$ & $\begin{array}{l}1 \\
2 \\
3\end{array}$ & $\begin{array}{l}285.6 \\
289.2 \\
286.7\end{array}$ & $\begin{array}{l}7.93 \\
9.42 \\
7.16\end{array}$ & $\begin{array}{l}0.99 \\
1.44 \\
1.29\end{array}$ & $\begin{array}{l}2.78 \\
3.26 \\
2.50\end{array}$ & 4.21 & + & $\begin{array}{l}1: 2 \\
1: 3 \\
2: 3\end{array}$ & $\begin{array}{l}2.08 \\
0.66 \\
1.19\end{array}$ & $\begin{array}{l}+ \\
- \\
-\end{array}$ \\
\hline \multicolumn{11}{|c|}{ Group CA } \\
\hline $\begin{array}{l}82 \\
57 \\
48\end{array}$ & $\begin{array}{l}1 \\
2 \\
3\end{array}$ & $\begin{array}{l}282.2 \\
285.4 \\
287.4\end{array}$ & $\begin{array}{l}9.11 \\
9.37 \\
7.60\end{array}$ & $\begin{array}{l}1.01 \\
1.24 \\
1.11\end{array}$ & $\begin{array}{l}3.23 \\
3.28 \\
2.64\end{array}$ & 5.63 & ++ & $\begin{array}{l}1: 2 \\
1: 3 \\
2: 3\end{array}$ & $\begin{array}{l}2.02 \\
3.32 \\
1.16\end{array}$ & $\begin{array}{l}+ \\
++ \\
+\end{array}$ \\
\hline
\end{tabular}

$+P<0.05++P<0.01$

Table 5

Reproductive indices of the individual breeding groups according to sequence of lactations

\begin{tabular}{llllllll}
\hline & Group & $\begin{array}{l}\text { Number } \\
\text { of } \\
\text { animals }\end{array}$ & $\begin{array}{l}\text { Inseminat-Conception } \\
\text { ion } \\
\text { index }\end{array}$ & $\begin{array}{l}\text { Inter- } \\
\text { rate } \\
\text { val } \\
\text { days }\end{array}$ & $\begin{array}{c}\text { SP } \\
\text { days }\end{array}$ & $\begin{array}{l}\text { Calving } \\
\text { interval } \\
\text { days }\end{array}$ \\
\hline \multirow{3}{l}{$\begin{array}{llllll}\text { lst } \\
\text { lactation }\end{array}$} & CR & 70 & 1.66 & 62.86 & 58,73 & 82.30 & 366.74 \\
& CA & 43 & 1.84 & 48.84 & 59.53 & 93.30 & 381.23 \\
& & 57 & 1.96 & 47.36 & 59.55 & 93.98 & 382.76 \\
2nd & CR & 57 & 1.83 & 50.88 & 54.75 & 82.88 & 369.26 \\
lactation & C & 31 & 1.61 & 51.61 & 55.19 & 78.03 & 363.89 \\
& CA & 48 & 2.17 & 47.92 & 53.46 & 97.00 & 380.98 \\
3rd & CR & 31 & 1.87 & 54.84 & 62.09 & 92.65 & 374.79 \\
lactation & C & 16 & 1.75 & 62.50 & 69.50 & 93.88 & 387.42 \\
& CA & 25 & 1.48 & 60.00 & 60.32 & 75.92 & 365.17 \\
\hline
\end{tabular}


Table 6

Evaluation of reproductive indices according to the sequence of lactations within the breeding groups compared

\begin{tabular}{|c|c|c|c|c|c|c|c|}
\hline \multirow[b]{2}{*}{ Index } & \multirow[b]{2}{*}{ Group } & \multirow{2}{*}{$\begin{array}{l}\text { Sequence } \\
\text { of lacta- } \\
\text { tions }\end{array}$} & \multirow[b]{2}{*}{$n$} & \multirow{2}{*}{$\bar{x}$} & \multirow{2}{*}{$\begin{array}{l}\text { Lactations } \\
\text { compared }\end{array}$} & \multicolumn{2}{|c|}{$t$ - test } \\
\hline & & & & & & value & $\begin{array}{l}\text { signifi- } \\
\text { cance }\end{array}$ \\
\hline \multirow{3}{*}{ 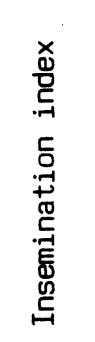 } & CR & $\begin{array}{l}\text { I } \\
\text { II } \\
\text { III }\end{array}$ & $\begin{array}{l}70 \\
57 \\
31\end{array}$ & $\begin{array}{l}1.67 \\
1.84 \\
1.87\end{array}$ & $\begin{array}{l}\text { I }: \text { II } \\
\text { I }: \text { III } \\
\text { II }: \text { III }\end{array}$ & $\begin{array}{l}0.865 \\
0.893 \\
0.172\end{array}$ & $\begin{array}{l}- \\
-\end{array}$ \\
\hline & $C$ & $\begin{array}{l}\text { I } \\
\text { II } \\
\text { III }\end{array}$ & $\begin{array}{l}43 \\
31 \\
16\end{array}$ & $\begin{array}{l}1.84 \\
1.61 \\
1.75\end{array}$ & $\begin{array}{l}\text { I }: \text { II } \\
\text { I : III } \\
\text { II }: \text { III }\end{array}$ & $\begin{array}{l}0.942 \\
0.255 \\
0.482\end{array}$ & $\begin{array}{l}- \\
-\end{array}$ \\
\hline & CA & $\begin{array}{l}\text { I } \\
\text { II } \\
\text { III }\end{array}$ & $\begin{array}{l}57 \\
48 \\
25\end{array}$ & $\begin{array}{l}1.96 \\
2.17 \\
1.48\end{array}$ & $\begin{array}{l}\text { I }: \text { II } \\
\text { I : III } \\
\text { II }: \text { III }\end{array}$ & $\begin{array}{l}0.807 \\
1.832 \\
2.330\end{array}$ & $\begin{array}{l}- \\
- \\
+\end{array}$ \\
\hline \multirow{3}{*}{ 要 } & CR & $\begin{array}{l}\text { I } \\
\text { II } \\
\text { III }\end{array}$ & $\begin{array}{l}70 \\
57 \\
31\end{array}$ & $\begin{array}{l}58.73 \\
54.75 \\
62.09\end{array}$ & $\begin{array}{l}\text { I }: \text { II } \\
\text { I }: \text { III } \\
\text { II }: \text { III }\end{array}$ & $\begin{array}{l}1.556 \\
0.917 \\
2.453\end{array}$ & $\begin{array}{l}- \\
+\end{array}$ \\
\hline & C & $\begin{array}{l}\text { I } \\
\text { II } \\
\text { III }\end{array}$ & $\begin{array}{l}43 \\
31 \\
16\end{array}$ & $\begin{array}{l}59.53 \\
55.19 \\
69.50\end{array}$ & $\begin{array}{l}\text { I }: \text { II } \\
\text { I }: \text { III } \\
\text { II }: \text { III }\end{array}$ & $\begin{array}{l}1.360 \\
2.300 \\
2.823\end{array}$ & $\begin{array}{l}- \\
+ \\
++\end{array}$ \\
\hline & CA & $\begin{array}{l}\text { I } \\
\text { II } \\
\text { III }\end{array}$ & $\begin{array}{l}57 \\
48 \\
25\end{array}$ & $\begin{array}{l}59.55 \\
53.46 \\
60.32\end{array}$ & $\begin{array}{l}\text { I }: \text { II } \\
\text { I }: \text { III } \\
\text { II }: \text { III }\end{array}$ & $\begin{array}{l}1.810 \\
0.173 \\
1.885\end{array}$ & $\begin{array}{l}- \\
-\end{array}$ \\
\hline \multirow{3}{*}{ के } & CR & $\begin{array}{l}\text { I } \\
\text { II } \\
\text { III }\end{array}$ & $\begin{array}{l}70 \\
57 \\
31\end{array}$ & $\begin{array}{l}82.30 \\
82.88 \\
92.65\end{array}$ & $\begin{array}{l}\text { I }: \text { II } \\
\text { I }: \text { III } \\
\text { II }: \text { III }\end{array}$ & $\begin{array}{l}0.075 \\
1.027 \\
1.006\end{array}$ & $\begin{array}{l}- \\
-\end{array}$ \\
\hline & C & $\begin{array}{l}\text { I } \\
\text { II } \\
\text { III }\end{array}$ & $\begin{array}{l}43 \\
31 \\
16\end{array}$ & $\begin{array}{l}93.30 \\
78.03 \\
93.88\end{array}$ & $\begin{array}{ll}\text { I } & : \text { II } \\
\text { I } & \text { III } \\
\text { II } & : \text { III }\end{array}$ & $\begin{array}{l}1.431 \\
0.040 \\
1.272\end{array}$ & - \\
\hline & CA & $\begin{array}{l}\text { I } \\
\text { II } \\
\text { III }\end{array}$ & $\begin{array}{l}57 \\
48 \\
25\end{array}$ & $\begin{array}{l}93.98 \\
97.00 \\
75.92\end{array}$ & $\begin{array}{l}\text { I }: \text { II } \\
\text { II }: \text { III } \\
\text { II }: \text { III }\end{array}$ & $\begin{array}{l}0.297 \\
1.713 \\
1.826\end{array}$ & $\begin{array}{l}- \\
-\end{array}$ \\
\hline \multirow{3}{*}{ 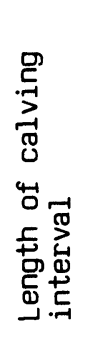 } & CR & $\begin{array}{l}\text { I } \\
\text { II }\end{array}$ & $\begin{array}{l}70 \\
57 \\
29\end{array}$ & $\begin{array}{l}366.75 \\
369.36 \\
374.79\end{array}$ & $\begin{array}{l}\text { I }: \text { II } \\
\text { I }: \text { III } \\
\text { II }: \text { III }\end{array}$ & $\begin{array}{l}0.333 \\
0.800 \\
0.602\end{array}$ & $\begin{array}{l}- \\
- \\
-\end{array}$ \\
\hline & C & $\begin{array}{l}\text { I } \\
\text { II } \\
\text { III }\end{array}$ & $\begin{array}{l}43 \\
31 \\
12\end{array}$ & $\begin{array}{l}381.23 \\
363.87 \\
387.42\end{array}$ & $\begin{array}{l}\text { I }: \text { II } \\
\text { I }: \text { III } \\
\text { II }: \text { III }\end{array}$ & $\begin{array}{l}1.606 \\
0.374 \\
1.604\end{array}$ & $\begin{array}{l}- \\
-\end{array}$ \\
\hline & CA & $\begin{array}{l}\text { I } \\
\text { II } \\
\text { III }\end{array}$ & $\begin{array}{l}57 \\
48 \\
24\end{array}$ & $\begin{array}{l}382.76 \\
380.98 \\
365.17\end{array}$ & $\begin{array}{l}\text { I }: \text { II } \\
\text { I }: \text { III } \\
\text { II }: \text { III }\end{array}$ & $\begin{array}{l}0.179 \\
1.515 \\
1.498\end{array}$ & $\begin{array}{l}- \\
-\end{array}$ \\
\hline
\end{tabular}




\begin{tabular}{|c|c|c|c|c|c|c|c|c|}
\hline \multirow[t]{2}{*}{ Index } & \multirow[t]{2}{*}{ Group } & \multirow{2}{*}{ 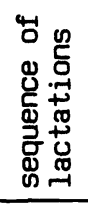 } & \multirow[t]{2}{*}{ Mated } & \multirow[t]{2}{*}{$\begin{array}{l}\text { Conception } \\
\text { after the } \\
\text { lst insemi- } \\
\text { nation }\end{array}$} & \multirow[t]{2}{*}{$\begin{array}{l}\% \text { of } \\
\text { concep- } \\
\text { tions }\end{array}$} & \multirow[t]{2}{*}{$\begin{array}{l}\text { Compar. } \\
\text { of } \\
\text { lacta- } \\
\text { tions }\end{array}$} & \multicolumn{2}{|c|}{$\begin{array}{l}\text { Test of the dif- } \\
\text { ference between } \\
\text { two relative } \\
\text { values }\end{array}$} \\
\hline & & & & & & & value & $\begin{array}{l}\text { signifi- } \\
\text { cance }\end{array}$ \\
\hline \multirow{3}{*}{ 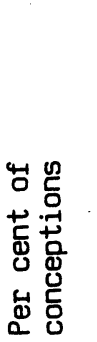 } & $C R$ & $\begin{array}{l}\text { I } \\
\text { III } \\
\text { III }\end{array}$ & $\begin{array}{l}70 \\
57 \\
31\end{array}$ & $\begin{array}{l}44 \\
29 \\
17\end{array}$ & $\begin{array}{l}62.88 \\
50.88 \\
54.84\end{array}$ & $\begin{array}{l}\text { I }: \text { II } \\
\text { I }: \text { III } \\
\text { II }: \text { III }\end{array}$ & $\begin{array}{l}1.351 \\
0.759 \\
0.359\end{array}$ & $\begin{array}{l}- \\
-\end{array}$ \\
\hline & C & $\begin{array}{l}\text { I } \\
\text { II } \\
\text { III }\end{array}$ & $\begin{array}{l}43 \\
31 \\
16\end{array}$ & $\begin{array}{l}21 \\
16 \\
10\end{array}$ & $\begin{array}{l}48.84 \\
51.61 \\
62.50\end{array}$ & $\begin{array}{ll}\text { I } & : \text { II } \\
\text { I } & : \text { III } \\
\text { II } & : \text { III }\end{array}$ & $\begin{array}{l}0.235 \\
0.934 \\
0.712\end{array}$ & $\begin{array}{l}- \\
-\end{array}$ \\
\hline & CA & $\begin{array}{l}\text { I } \\
\text { II }\end{array}$ & $\begin{array}{l}57 \\
48 \\
25\end{array}$ & $\begin{array}{l}27 \\
23 \\
15\end{array}$ & $\begin{array}{r}47.36 \\
47.92 \\
60.00\end{array}$ & $\begin{array}{l}\text { I }: \text { II } \\
\text { I }: \text { III } \\
\text { II }: \text { III }\end{array}$ & $\begin{array}{l}0.057 \\
1.051 \\
0.982\end{array}$ & $\begin{array}{l}- \\
- \\
-\end{array}$ \\
\hline
\end{tabular}

$+\quad P<0.05$

$+\quad P<0.01$

When comparing the results of $V$ á cha l et al. (1976), S u chá $n e k$ and $\mathrm{Neje} \mathrm{zchleba} \mathrm{(1977),} \mathrm{Such} \mathrm{ánek} \mathrm{et} \mathrm{al.} \mathrm{(1977)}$ who reported that gravidity in the CR crosses was shorter by 0.5 - 4.3 days as compared with herd mates of group $C$, also the present results showed that gravidity in the CR and CA crosses was shorter than that of group $C$. The shortened gravidity is favourable since it shortens the calving interval in dairy cows.

The attention which the authors devoted to the individual reproductive indices was different. Such ánek (1978) reported that the A.I. index in the CR crosses was lower (1.23) than in group $C$ by 0.34 . The values found in the present study are also lower in the $C R$ crosses for the 2nd and $3 \mathrm{rd}$ lactations. In the CA crosses the value was lower only for the $3 r d$ lactation as compared with group $C$. The values of the A.I. index ranged within the values given by Urban et al. (1979).

U l r y ch (1978) found that the A.I. index in the CA crosses after the first insemination was 57.4 - $58.5 \%$. S uchánek et al. (1984) reported that the conception rate in the CA crosses was higher by $1.6 \%$ than in group C. The conception rate in the groups investigated in the present study was the best in the $C R$ crosses, whereas in groups $C$ and $C A$ it was considerably low. With regard to the values obtained, this index is favourable, especially for the lst lactation in the CR crosses and in all the groups in the 2nd lactation.

K o n č a r (1979) found a significant difference in the length of the interval between the lst and 2 nd calvings in the slovakian Red Pied $X$ Red Holstein crosses. In the groups compared in the present study, a significant difference in the length of the interval in the CR crosses was observed between the 2 nd and $3 r d$ lactations. The length of the interval found is favourable, with the exception of group $C$ in the $3 r d$ lactation. 
Many authors analyzed the fertility on the basis of the length of the SP; P o lás ek and S u chá nek (1973), U r b a $n$ et al. (1979), Suchán ek (1980), S u chánek and B o ž o vský (1983) reported that the SP in the CA crosses was shorter by 3.3 - 10.1 days. In analyses of the groups of the present study, in none of the cases were the highest sp values reached as given by other authors.

P o l ás e k and S u chánek (1973), Suchánek (1973) and $\checkmark$ ách a l (1983) analyzed the length of the calving interval which they found to be 365 - 393 days in the individual groups of crosses, the difference as compared with herd mates of group $C$ being 7 - 18 days. The length of the calving interval can be evaluated as very good, in group $C$ for the lst and $3 r d$ lactations, and in the CA crosses for the 2 nd lactation as satisfactory, what is in accord with data given by $V$ ách a 1 (1983).

\section{Studium reprodukčnich ukazatelủ křrženek českého strakatého} skotu $s$ plemenem ayrshirským a červeným holštýnským

Průměrný věk jalovic při zabřeznutí byl nejnižší u kříženek CR (509,35 dní), pak následovala skupina C (521,09 dní) a CA (522,72 dní). Prùměrný věk při 1 . otelení byl opět nejnižsí ve skupině kírženek CR (789,76 dni), následovala skupina CA (804,90 dní) a C (806,72 dní). Nejkratší aélku gravidity na I. až III. laktaci měly křiženky CR (I. 280,4l, II. 283,60, III. $286,60 \mathrm{dni})$. Na I. laktaci činil inseminační index u kŕíženek CR 1,66 , u kł̌ženek CA 1,96 a u skupiny C 1,84 ; na II. laktaci u CR 1,83, u C 1,61 a u CA 2,17; na III. laktaci u CR 1,87, u C 1,75 a u CA 1,48 . Procento zabreznutí po 1 . inseminaci bylo u CR na I. laktaci $62,86 \%$, u C $48,84 \%$ a u CA $47,36 \%$; na II. laktaci u CR $50,88 \%$, u C $51,61 \%$ a u CA 47,92\%; na III. laktaCi u CR 54,84\%, u C $62,50 \%$ a u CA 60,00\%. Délka intervalu na I. laktaci byla zjištěna u CR 58,73 , u C 59,53 a u CA 59,55 dní; na II. laktaci u CR 54,75, u C 55,19 a u CA 53,46 dní; na II. laktaci u Cr 62,09 , u C 69,50 a u CA 60,32 dní. Délka SP na I. laktaci dosahovala u CR 82,30 , u C 93,30 a u CA 93,78 dní; na II. laktaci u CR 83,88, u C 78,03 a u CA 97,00 dní; na III. laktaci u CR 92,65 , u C 93,88 a u CA 75,99 dní. Mezidobí činilo na I. laktaci u CR 366,74, u C 381,23 a u CA 382,76 dní; na II. laktaci u CR 369,26 , u C 363,89 a u CA 380,98 dní; na III. laktaci u CR 374,79 , u C 387,42 a u CA 365,17 dní. Při zhodnocení reprodukčních ukazatelú jednotlivých plemenných skupin dle pořadí laktace jeví se nejprriznivěji tito ukazatelé u skupiny CR na I. laktaci, zatímco na II. laktaci se projevila lépe skupina C a na III. laktaci kříženky CA. V rámci skupin na všech třech laktacích však nebyly $v$ reprodukčních ukazatelích zjistěny statisticky významné rozdily. Celkově možno hodnotit reprodukční ukazatele jako př́znivé. 


изучение показателей репродукции помесей.четского
пятнистого племени и с айтирским и . красным
гольштейским племенами

Средний возраст нетелей при зачатии был самый низкий у помесей CR $(509,35$ суток), после следования группа C $(521,09$ суток) и CA $(522,72$ суток). Самый низкий возраст при первом отеле был в группе помесей CR $(789,76$ суток), следовали группы CA $(804,90$ суток) и С $(806,72$ суток). Самая короткая продолжительность в 1 - III лактации была у помесей CR $(1$ - 280,41, II - 283,60, III286,60 суток). Индехс осеменения в 1 лактации достигал у помесей $C R 1,66$, у помесей CA 1,96 и у группы C 1,84 ; в период II лактации У CR - 1,83, С - 1,61 и CA 2,17; в лактации у CR 1,87, C 1,75 и CA - 1,48. Процент забеременения после 1 осеменения достигал У CR В 1 лактации 62,868, У C - 48,848, СА- 47,368; во II лахтации - CR - 50,888, C - 51,618 и CA - 47,928; В III лактации $C R-54,848, C-62,508$ и CA - 60,008. Продолжительность интервала в 1 лактации была определена у CR 58,73, C 59,53 и CA 59,55 суток, во II лактации у CR 54,75 , С 55,19 и CA 53,46 суток; в III лактации - CR 62,09, С 69,50 и CA 60,j2 суток. Продолжительность CP service period) в 1. лактации достигала у CR 82,30 , С 93,30 и CA 93,78 суток; в период II лактации у CR 83,88 , С 78,03 и CA 97,00 суток; в III лактации - Y CR 92,65, C - 93,88 и CA 75,99 суток. Промежуточный период достигал в 1 лактации у CR 366,74 , С - 381,23 и CA - 382,76 сүток, во II лактации - У CR 369,26, C - 363,89 и CA 380,98 суток, в III лактации CR 374,79, С - 387,42 и CA - 365,17 суток. В ходе оценки показателей репродукции отдельных племенных групп по порядху лактации самым благоприятным являются показатели Y грYппы CR в 1 лактации, между тем как во II лактации лучше они у группы С и в III лахтации у помесей СА. В группах во всех трех лактациях однако в показателях репродукции не было установлено статистически значимой разницы. В итоге можно показатели репродукции считать благоприятными .

References

CHRENEK, J.- PLESNIK, J.: Mlieková úžitkovost kríženiek $F_{1}$ gen. slovenského strakatého s červenostrakatým nížinným (Mass 1 -Rhein-Iselským) plemenom. Project report, Nitra, VúžV, 1975: 56 .

KONČAR, L. - SIMIĆ, M. - ANTOV, A. - VUČINIĆ, J. - JOVIČEVIĆ, S.: Efekti ukrštanja domaćeg šarenog sa holštajn-frizijskim govečetom na mlečne i reprodukcíjske osobine. Savrem. Poljopriv., 27, 1979: 505 - 520 .

POLASEK, M. - SUCHÁNEK, B.: Výsledky křižení ayrshirských plemenic s býky českého strakatého skotu $v$ jednom stádě. Výzk. Chovu Skotu, 15, 1973: 5 - 11.

SUCHÁNEK, B.: Vý̀́ledky chovu ayrshirského skotu v ČSR. Výzk. Chovu Skotu, 15, 1973: 20 - 25.

SUCHÁNEK, B.: Některá hilediska zušlechtovacího křížení českého strakatého plemene vČSR. Výzk. Chovu Skotu, 16, 1974: 32 - 37. 
SUCHÁNEK, B. - NEJEZCHLEBA, J.: Prủběh porodủ, mortalita a hmotnost telat u ǩ̌fžencú $F$ gen. Český strakatý $x$ červený holštýnský skot. Project report. Rapotín, VúcHS, 1976: 46.

SUCHÁNEK, B. - ULRYCH, A.: Stupeñ a přičiny vyřazování křiženek českého strakatého plemene s ayrshirským. Živoč. Výr., 2l, 1976: 727 - 733.

SUCHÁNEK, B. - NEJEZCHLEBA, J.: Délka březosti a hmotnost telat při křížení plemen české strakaté a červené holstýnské. Živoč. Výr., 22, 1977: $417-426$.

SUCHÁNEK, B. - ULRYCH, A. - NEJEZCHLEBA, J.: Mléčná užitkovost kř́ženek českého strakatého plemene s ayrshirským podle celostátních sestav kontroly užitkovosti. Živoč. Výr., 22, 1977 : $95-103$.

SUCHANEK, B.: Mléčná užitkovost kříženek plemene českého strakatého a ayrshirského $z$ hlediska dlouhověkosti. Výzk. Chovu Skotu,

SUCHÁNEK, B. - GOLDA, J. - ULRYCH, A.: MléČná užitkovost kříženek českého strakatého plemene s červeným holstýnským (CR 25)

za zkrácené 100 denní laktace. Project report. Rapotín, Vúchs, 1978 : 46 .

SUCHÁNEK, B. - GOLDA, J. - ULRYCH, A. - POLES, V.: Zhodnocení I. etapy zušlechtovacího křižení českého strakatého plemene $s$ červeným holštýnským. Project report. Rapotín, VúCHS, 1979: 57.

SUCHANEK, B.: Zušlechtovací kŕižení skotu v ČSR ve výsledcích kontroly užitkovosti za rok 1978. Výzk. Chovu Skotu, 21, 1979: . $51-54$.

SUCHANEK, B. - ULRYCH, A. - BOŽOVSKÝ, A.: UŽitkovost kříženek ve velkokapacitnich kravínech. Project report. Rapotín, VúcHS, 1980.

SUCHÁNEK, B.: Výsledky kontroly užitkovosti za rok 1979 se zřetelem na užitkové typy skotu. Výzk. Chovu Skotu, 22, 1980: $14-16$.

SUCHÁNEK, B. - KRAL, .M. - FRELICH, J.: Plodnost dojnic v podmínkách prủmyslové technologie chovu. In: Sbor. Prov. ekon. Fak. Č. Budějovice, 1981: 163 - 172 .

SUCHANEK, B. - BOŽOVSKÝ, A.: Jaké typy krav pro velkokapacitní stáje.'Zeměd. Nov., Zemědělec, 25.1.1983: 3.

SUCHÁNEK, B. - GOLDA, J. - ULRYCH, A. - STRNADEL, Z . : Výsledky zušlechtovacího kŕǐzení českého strakatého plemene s ayrshirským a červeným holstýnským. Project report. Rapotín, VúCHS, $1984,52$.

ULRYCH, A. - SUCHANEK, B.: Užitkové vlastnosti křiženek druhé filiálni generace českého strakatého skotu s ayrshirským plemenem. Výzk. Chovu Skotu, 19, 1977: 13 - 17.

ULRYCH, A.: První výsledky kř́ižení po ayrshirských býcích importovaných z Kanady. Výzk. Chovu Skotu, 20, 1978: $22-24$.

URBAN, F. - DVOŔÁCEK, M. - PILAT, Z. - BURDA, J.: Zhodnocení užitkových vlastností křiženek's černostrakatým skotem $v$ podmínkách velkovýrobních technologií. Project report. Uhŕíněves. VÚŽV, 1979: 39.

VÁCHAL, J. - SUCHANEK, B. - NEJEZCHLEBA, J.: Prủběh porodú, mortalita telat při narození u křženek F, gen. Český strakatý $x$ $x$ červený holštýnský skot. Project report. Uhříněves, vúžv, Rapotín, VúcHS, 1976: 77.

VÁCHAL, J.: Realizace komplexniho programu šlechtění českého strakatého skotu. Project report. Uhŕíněves, VúžV, 1983: 75. 